\title{
Daughters prepare to lead family firms
}

\section{Kimberly Eddleston (Northeastern University)}

\section{KEYWORDS: Leadership, Family Business, Women.}

Daughters are increasingly assuming leadership roles at family firms. In this video, familybusiness.org Editor Kimberly Eddleston talks with two Northeastern University students who will join their family firms after graduation: Angelina Kljat, whose family runs an international agricultural company in Kazakhstan, and Joanna Jacob, whose family owns a large Indonesian shipping company. Both women talk about the expectations of their families back home, their worries and their hopes for the future. The takeaway: Figure out how you want to contribute, be confident and know your value. 